\title{
Reprezentativní výzkum fandovství fotbalu a popularity pražských ligových klubů
}

\section{Analysis of the fans base and popularity of Prague league football teams}

\author{
Radek Tahal
}

Fakulta podnikohospodářská Vysoké školy ekonomické v Praze

\begin{abstract}
Abstrakt:
$V$ poslednich letech je patrné stále hlubši prolínání sportu a marketingu. Př̀ikladem může být sponzoring profesionálních $i$ amatérských sportovnich soutěži, ale také marketingová komunikace s fanoušky sportovnich klubů či prodej reklamnich a upominkových prededmètü. Pro sport je z marketingového pohledu mimo jiné charakteristická dlouhodobá loajalita a př́zeň fanouškỉ jednotlivých klubi̊. A právě tento rys je pro využití $v$ marketingu velmi atraktivní.

Tato studie si klade za cil formou reprezentativního marketingového šetřeni provést analýzu fanouškovské základny pražských fotbalových ligových klubů. Nejprve se zjištuje, jaké procento populace se o fotbal zajímá. Následně je tato část populace posuzována podle sociodemografických charakteristik. Hlavním výstupem pak je klasifikace pražských ligových fotbalových klubi̊ podle procenta př́znivců, kteři sledovaným klubuim fandí.

Analýze jsou podrobeny i otázky týkajíci se celoživotni loajality ke konkrétnimu fotbalovému klubu a dédičnosti fandovství klubu v rámci rodiny.

Využití této studie se predpokládá v oblasti sportovního marketingu, zejména pro nastavení marketingové komunikace mezi fotbalovými kluby a jejich fanoušky a pro usnadnění designu aktivačních kampaní sponzorských firem.
\end{abstract}

\section{Abstract:}

In recent years, close interconnection between sports and marketing can be noticed. As an example we can mention sponsorship as well as targeting in connection with ticketing and merchandising. Sports disciplines and sports clubs are characterized by long time loyalty of their fans. This typical sports feature has become attractive for company marketers.

This paper aims at analyzing the fans base of Prague league football teams. The method of representative marketing survey is applied to achieve this goal. First, the percentage of the Prague population that is interested in football is analyzed. Thereafter the indentified fans base is classified by socio-demographic characteristics. The key issue of the article is the percentage categorization of Prague population supporting each of the league clubs.

Further on are also analyzed topics like lifelong loyalty to the club and heredity of the fandom.

This study wants to bring practical results to professionals who are engaged in sports marketing, mainly in marketing communication and sponsorship.

Klíčová slova: Sportovni marketing, marketingový výzkum, reprezentativní šetřeni, pražské ligové fotbalové kluby, fotbalový fanoušek

Key words: Sports marketing, market research, representativeness, Prague league football clubs, football fan

Př́spěvek byl vytvořen z prostředků institucionální podpory na dlouhodobý koncepční rozvoj výzkumné organizace VŠE IP300040. 


\section{ÚVOD}

\section{Sportovní marketing}

Marketing prolíná všechny obory a disciplíny, které jsou nějakým způsobem spojeny s trhem. Marketingu se věnují jednotlivci i firmy. Politici soupeří o hlasy voličůu, umělci usilují o posluchače s cílem získat popularitu a slávu. Nejinak je tomu i v oblasti sportu. Sportovní marketing se etabluje jako samostatná a velmi uznávaná disciplína. Propojování firemních strategií se sportem je stále častější a přináší oboustranný prospěch. O významu tohoto propojení svědčí i to, že dnes již rozlišujeme dvě poddisciplíny „sport v marketingu“ a „marketing ve sportu“. Problematika propojení sportu a marketingu se v literatuře objevuje zejména v posledním desetiletí. Problematikou se zabývají např. Ratten (2011), Fullerton (2008), Lee (2010).

Sport v marketingu označuje situaci, kdy firmy prodávají své produkty pomocí sportu. Typickým př́íkladem je propagace firem prostřednictvím sponzorování sportovních utkání nebo spolupráce se sportovci jako brand ambasadory. Znamená to, že firma spojí propagaci a positioning své značky s tváŕí známého sportovce.

Marketing ve sportu zahrnuje aktivity, které napomáhají propagaci a popularizaci sportovních akcí za účelem přilákání zájmu veřejnosti, médií a firem.

\section{Specifika sportovních fanoušků jako účastníků marketingového procesu}

Ve většině podnikatelských sektorů je jednou z klíčových aktivit marketingových pracovníků vytváření loajalitních a retenčních programů, vztažených ke konkrétní značce. Karlíček (2013) říká že: „Dobrá značka zvyšuje vnímanou hodnotu jí zaštítěných produktů“. Přeliv zákazníků ke konkurenci znamená pro firmu vždy snížení výnosů a současně zvýšení nákladů, v souvislosti s akvizicí klientů nových.

Jedním z fenoménů sportovního marketingu je vysoká věrnost fanoušků. Sportovní prríznivec jen velmi zř́́dka mění svůj oblíbený sport nebo sportovní klub. Dokonce je sportovní odvětví mimořádné i v tom, že sportovní fanoušek sám aktivně informace o svém oblíbeném sportu a klubu vyhledává. Z tohoto důvodu je zejména nyní, v období kdy se v důsledku technologického pokroku neustále zkracují životní cykly produktů, spojení firem se sportem mimořádně atraktivní; viz např. Rosca (2011), Irwing (2010).

Právě proto je synergie se sportem firmami velmi vyhledávaná. Sportovní celebrita na sebe dlouhodobě přitahuje pozornost relativně stálého segmentu populace. Druhým důležitým aspektem je, že sportovní fanoušek je díky věrnosti svému klubu pro firmy snáze identifikovatelný a dosažitelný. Pokud známe charakteristiku sportovního fanouška, můžeme podle toho propojit jeho zájem o sportovní disciplínu s vhodně zacílenou marketingovou komunikací. Toto propojení je dnes navíc významně ulehčeno díky technologickým možnostem jak při identifikaci profilu fanoušků, tak následném cílení marketingové komunikace, které zejména v prostř̌edí internetu nabízí velmi pestré možnosti (viz Stř́iteský, 2011).

Znalost fanouškovské základny je klíčová jak pro nastavení marketingových aktivit samotného sportovního klubu, tak i pro spolupracující firmy. Sportovní klub řídí na základě těchto informací zejména proces prodeje vstupenek (ticketing) a výrobu a distribuci reklamních či upomínkových předmětů (merchandising). Firmy, které se rozhodnou spolupracovat s klubem formou sponzoringu či propůjčí soutěži svůj firemní název (titulární partner), potřebují mít informace o počtu fanoušků a znát jejich základní profil. Pro sponzoring je klíčové, aby byla efektivně zasažena požadovaná cílová skupina potenciálních zákazníků.

\section{Marketingový výzkum pro potřeby fotbalových klubů}

V rámci marketingových aktivit se často setkáváme s použiváním ankety. To je bezesporu jedna z možností, jak získat informace od určitých skupin populace. Nutno však podotknout, že anketa není reprezentativní, protože se jí účastní pouze respondenti, kteří na ni někde narazí a sami se rozhodnou anketní formulář vyplnit. V jistých specifických situacích sice může mít využití ankety své opodstatnění, ale v naprosté většině př́ípadů přináší pouze deklaraci od těch respondentů, kteří jsou momentálně bud' v pozitivním, nebo negativním emočním rozpoložení ve vztahu ke sledovanému tématu.

$\mathrm{Z}$ tohoto důvodu jsme se pro potřeby vypracování této studie jednoznačně rozhodli nikoli pro anketu, ale pro marketingový výzkum založený na reprezentativním výběrovém šetření.

Účelem této studie je reprezentativní marketingový výzkum fanouškovské základny pražských fotbalových klubi̊. 
Hlavní výzkumné otázky:

1. Kolik procent pražské populace fandí fotbalu?

2. Jaké je rozložení fanoušků mezi pražské ligové fotbalové kluby?

3. Jak se liší fanouškovská základna při tř́iění podle pohlaví, věku a vzdělání?

4. Má sídlo klubu a rezidenční čtvrt' fanouška vliv na volbu oblíbeného klubu?

Související výzkumná témata:

- Profil fotbalového fanouška

- Dědičnost fandovství v rámci rodiny

\section{METODIKA}

\section{Způsob definování výběrového souboru}

Studie je založena na reprezentativním sociologickém průzkumu obyvatel města Prahy, jejich vztahu k fotbalu a fandovství jednotlivým pražským ligovým klubům.

Velký důraz byl kladen na maximální přesnost sběru dat. Sběr dat byl realizován v období 10.3.-12.4.2013. Velikost vzorku byla 401 respondentů. Pro dosažení reprezentativnosti byl použit kvótní výběr respondentů. Jako kvótní proměnné byly zvoleny sociodemografické znaky, konkrétně pohlaví, věk, vzdělání a místo bydliště (v tomto prŕípadě pražské městské části 1-10).

Data o složení základního souboru (struktuře populace) byla čerpána z oficiálních údajů Českého statistického úřadu. Velikost vzorku respondentů byla navržena tak, aby na hladině významnosti $1-\alpha=0,95$ bylo dosaženo intervalu spolehlivosti pod $5 \%$. V našem konkrétním případě bylo dosaženo hodnoty intervalu spolehlivosti $4,89 \%$.

Struktura dotazovaných podle kvótních znaků byla následující:

Tab. 1: Struktura výběrového souboru

\begin{tabular}{|c|c|c|c|c|c|}
\hline Kvóta & Proměnná & Hodnota & Kvóta & Proměnná & Hodnota \\
\hline \multirow{2}{*}{ Pohlaví } & muži & $48 \%$ & \multirow{10}{*}{ Region } & Praha 1 & $2 \%$ \\
\hline & ženy & $52 \%$ & & Praha 2 & $4 \%$ \\
\hline \multirow{5}{*}{ Věk } & $0-19$ & $16 \%$ & & Praha 3 & $6 \%$ \\
\hline & $\frac{20-29}{30-39}$ & $16 \%$ & & Praha 4 & $22 \%$ \\
\hline & $\frac{30-39}{40-49}$ & $\frac{19 \%}{13 \%}$ & & Praha 5 & $14 \%$ \\
\hline & $50-64$ & $19 \%$ & & Praha 6 & $12 \%$ \\
\hline & 65 a více & $17 \%$ & & Praha 7 & $3 \%$ \\
\hline \multirow{3}{*}{ Vzdělání } & $\frac{\text { základní }}{\text { bez maturity }}$ & $\frac{12 \%}{23 \%}$ & & Praha 8 & $9 \%$ \\
\hline & s maturitou & $39 \%$ & & Praha 9 & $14 \%$ \\
\hline & vysokoškolské & $26 \%$ & & Praha 10 & $14 \%$ \\
\hline
\end{tabular}

Do úvodu dotazníku byla zařazena filtrační otázka, která zajistila, že do dotazování budou zahrnuti pouze respondenti, kteří bydlí na území města Prahy. 


\section{Zpiosob analýzy získaných dat}

Klíčovým momentem celého výzkumu bylo zmapovat pražskou populaci z hlediska zájmu o fotbal a následně přinést odpověd' na otázku, kolik procent z celkové množiny fotbalových fanoušku mají jednotlivé ligové pražské fotbalové kluby.

Výzkum byl cílen zejména na pět pražských ligových klubů:

- AC Sparta Praha

- Bohemians 1905

- FK Dukla Praha

- $\quad$ FK Viktoria Žižkov

- SK Slavia Praha

Získané odpovědi byly analyzovány za celý výběrový soubor jako celek, následně bylo také provedeno tř́ídění 1 . stupně podle jednotlivých kvótních znaků.

Jednou ze základních charakteristik sportovního klienta (fanouška) je vysoká věrnost a loajalita vůči oblíbenému klubu. Proto bylo analyzováno i to, jaké procento fanoušků v průběhu života změní svůj favorizovaný klub a do jaké míry je fandovství klubu v rámci rodiny dědičné. V neposlední řadě bylo analyzováno fandění jednotlivým fotbalovým klubům podle bydliště fanoušků v jednotlivých městských částech.

\section{VÝSLEDKY}

Prezentované údaje jsou výsledky reprezentativního výzkumu realizovaného na pražské populaci. Pro úplnost je dobré dodat, že velikost pražské populace je podle Českého statistického úřadu 1246780 obyvatel.

\section{Fandovství fotbalu mezi pražskou populací}

$\mathrm{V}$ této podkapitole jsou analyzována data, která se týkají vztahu pražské populace $\mathrm{k}$ fotbalu. Př́iznivci fotbalu jsou charakterizováni podle sociodemografických charakteristik.

Průzkumem bylo zjištěno, že fotbalu fandí 79 \% pražské populace, a to 89 \% mužů a 69 \% žen.

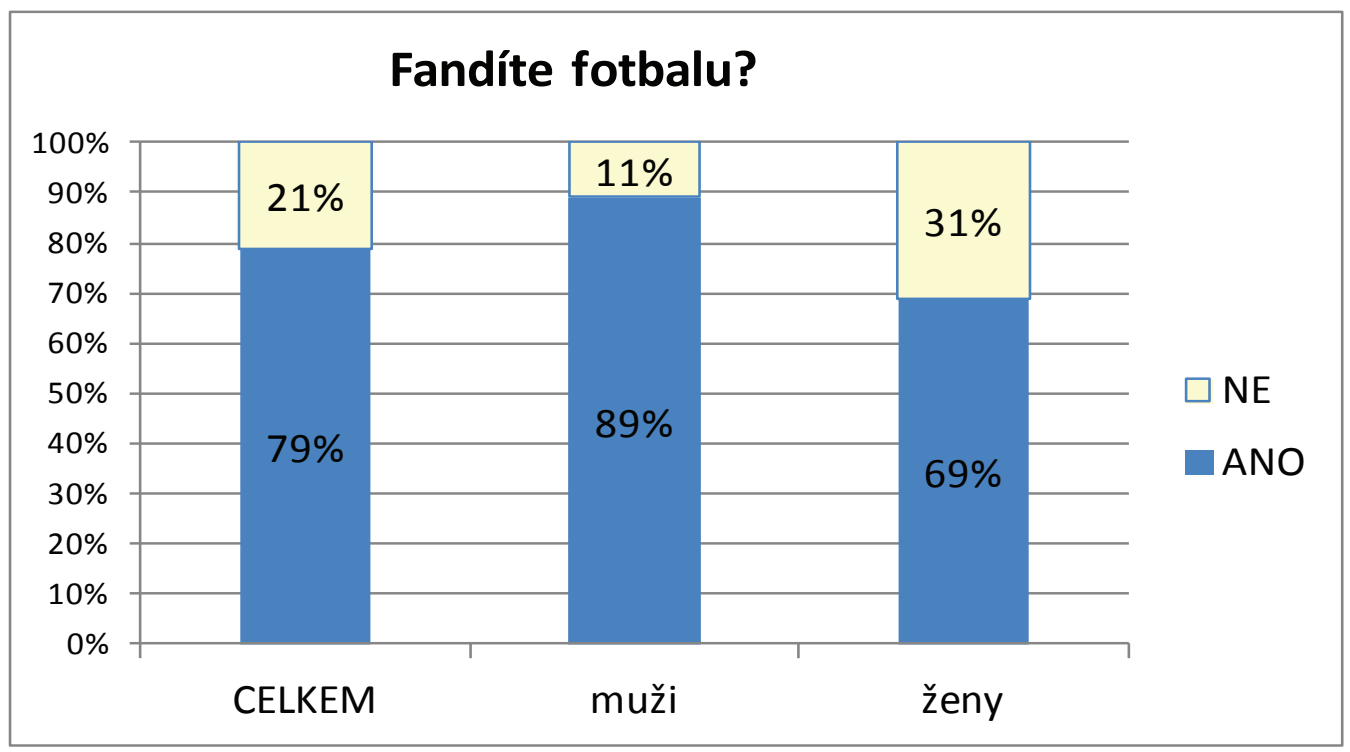

Graf 1: Fandovství fotbalu mezi pražskou populací v procentech 
Dalším pohledem je fandovství fotbalu podle věku. Největší podíl fanoušků je mezi nejmladší a nejstarší generací.

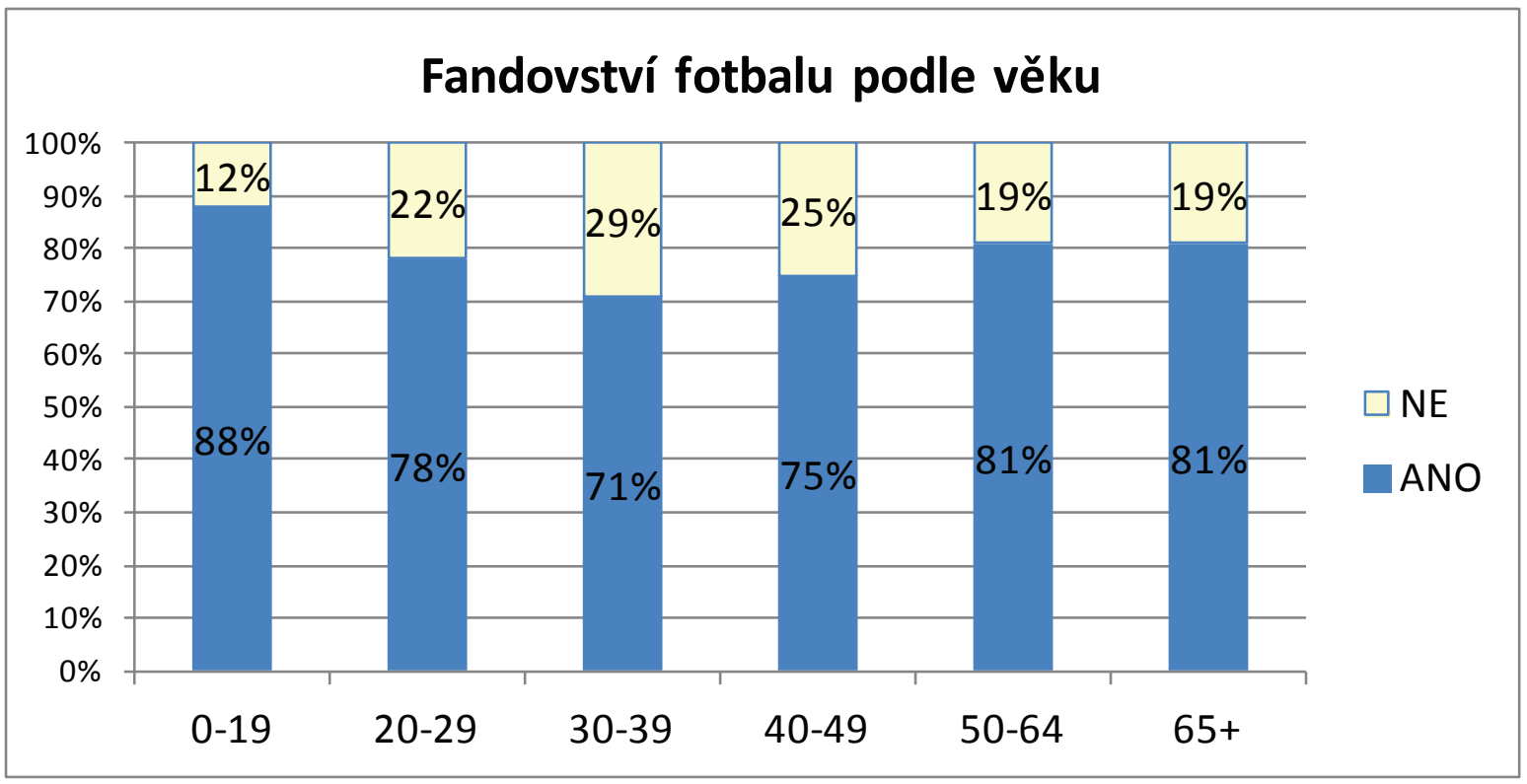

Graf 2: Fandovství fotbalu mezi pražskou populací podle věku v procentech

Fotbalu fandí spíše lidé s nižším vzděláním. Tento fakt je ale dán do značné míry tím, že příznivci fotbalu jsou z podstatné části mladí lidé do dvaceti let, kteří vzhledem ke svému věku ještě vyššího stupně vzdělání nedosáhli.

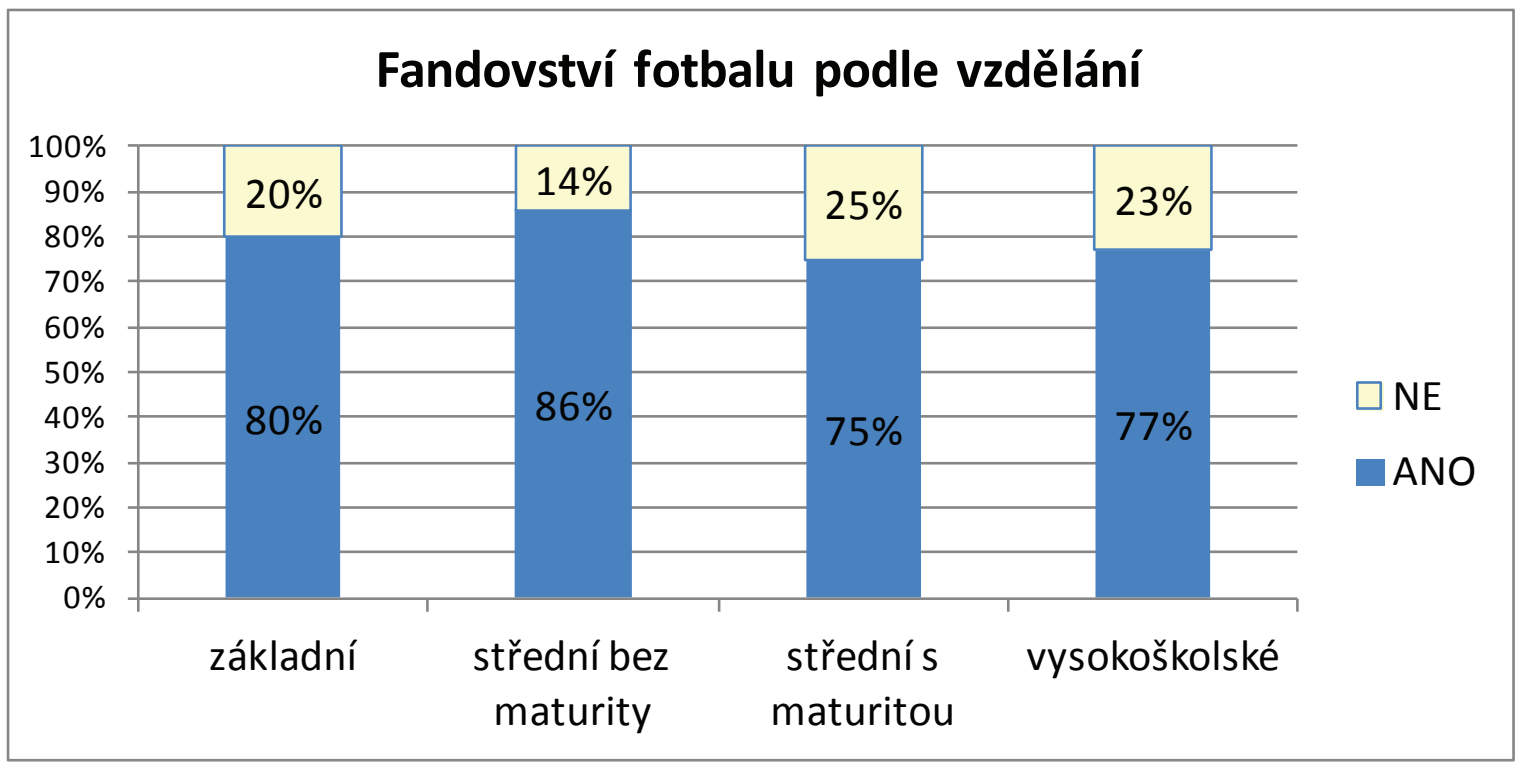

Graf 3: Fandovství fotbalu mezi pražskou populací podle vzdělání v procentech 
Následně bylo zjištováno, jaké procento z těch, kteří sledují fotbal obecně, fandí některému z pražských fotbalových klubů. Celkově je to 79 \%, mužů je 87 \%, žen 69 \%.

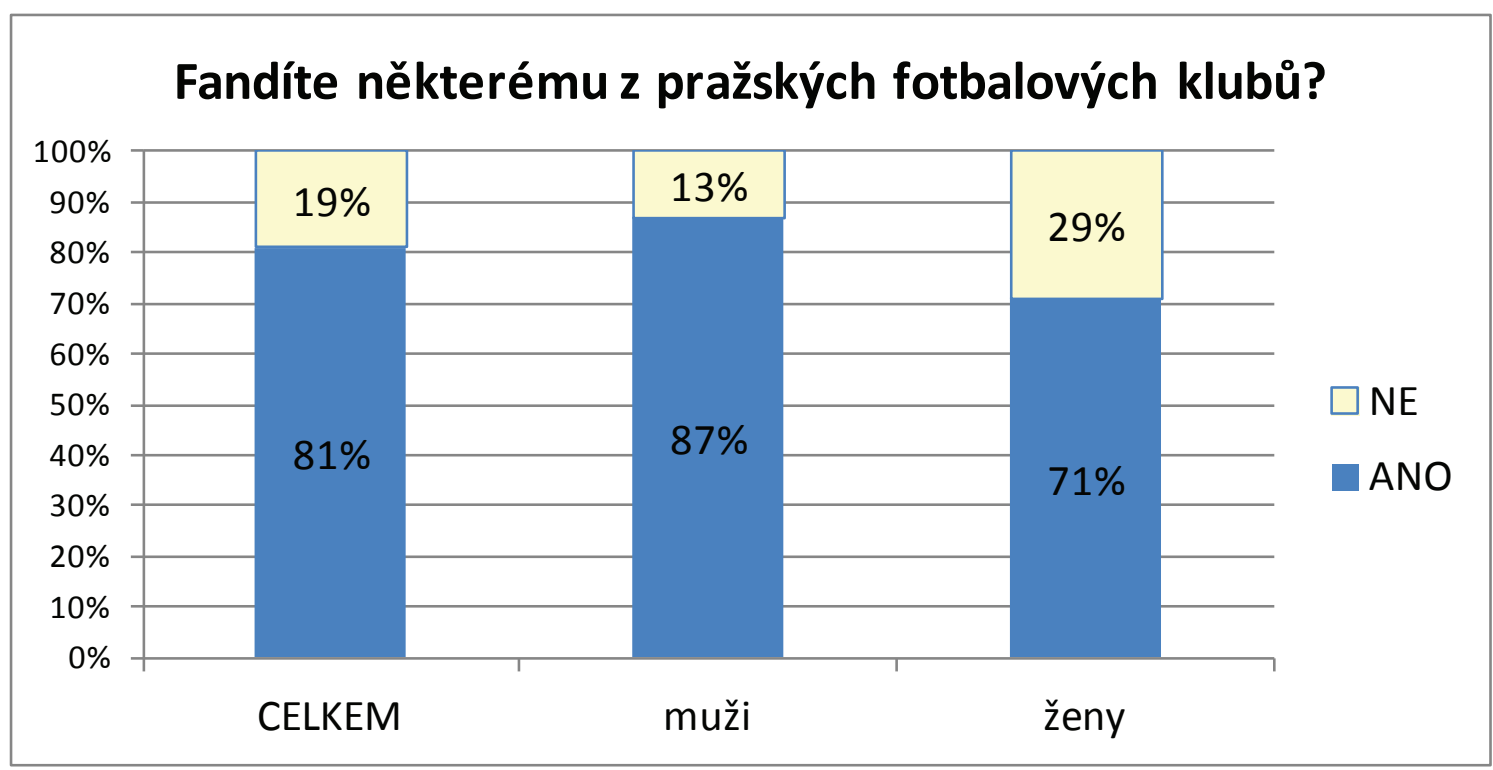

Graf 4: Fandovství některému z pražských fotbalových klubů v procentech

Následuje analýza fandovství fotbalu podle městské části bydliště respondentů. Fandovství konkrétnímu fotbalovému týmu je významné v Praze 10, kde sídlí SK Slavia Praha a Bohemians 1905. Naopak v Praze 1 a 5 je toto kritérium nejméně významné. V těchto městských částech nesídlí žádný tradiční fotbalový klub.

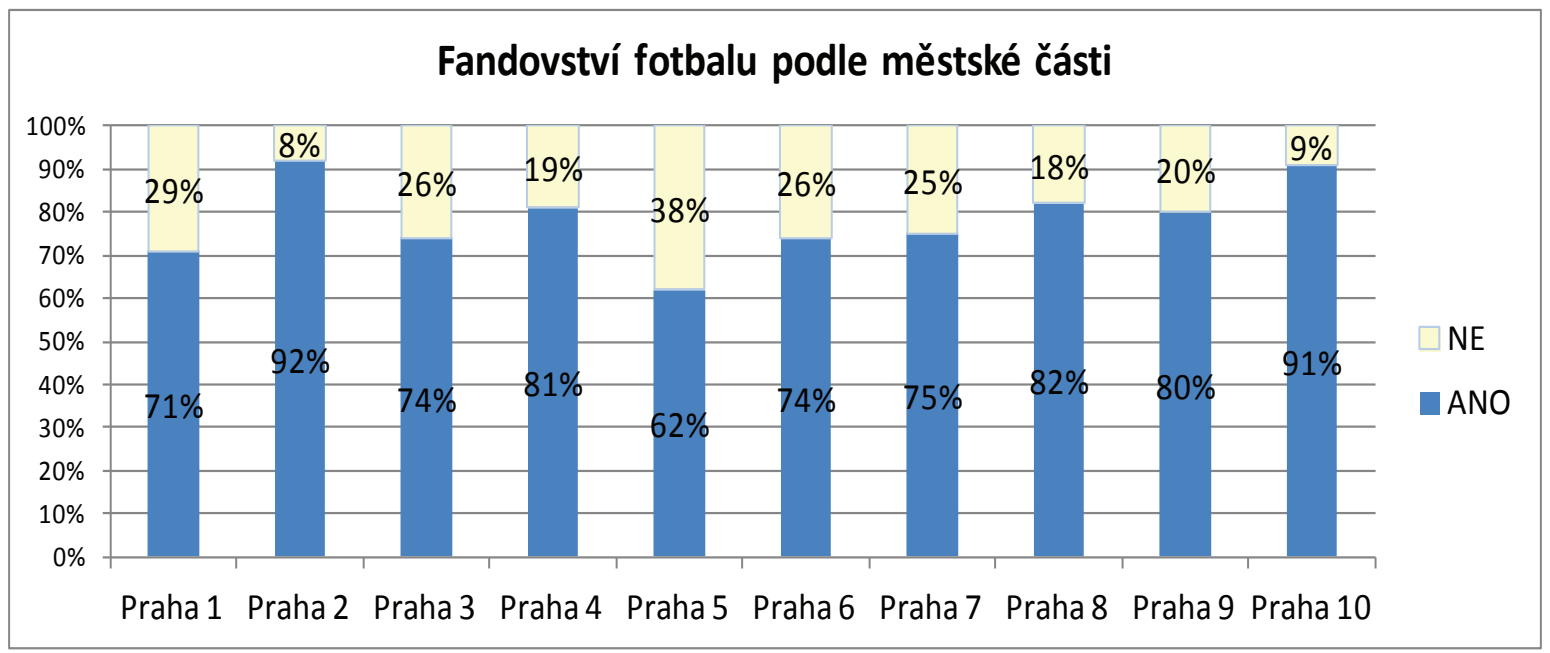

Graf 5: Fandovství fotbalu mezi pražskou populací podle bydliště v jednotlivých pražských městských částech

Rozložení fanoušků mezi pražské ligové fotbalové kluby

V následující kapitole jsou kromě postoje $\mathrm{k}$ fotbalu analyzovány jednotlivé pražské fotbalové ligové kluby podle velikosti své fanouškovské základny.

Z provedeného výzkumu vychází nejlépe AC Sparta Praha, která má 48 \% ze všech fanoušků pražského ligového fotbalu. Naopak nejnižší hodnoty vykazují kluby FK Dukla Praha a FK Viktoria Žižkov, oba shodně po 7 \% ze všech fanoušků pražského ligového fotbalu. 


\section{Rozložení fanoušků mezi pražské ligové kluby}

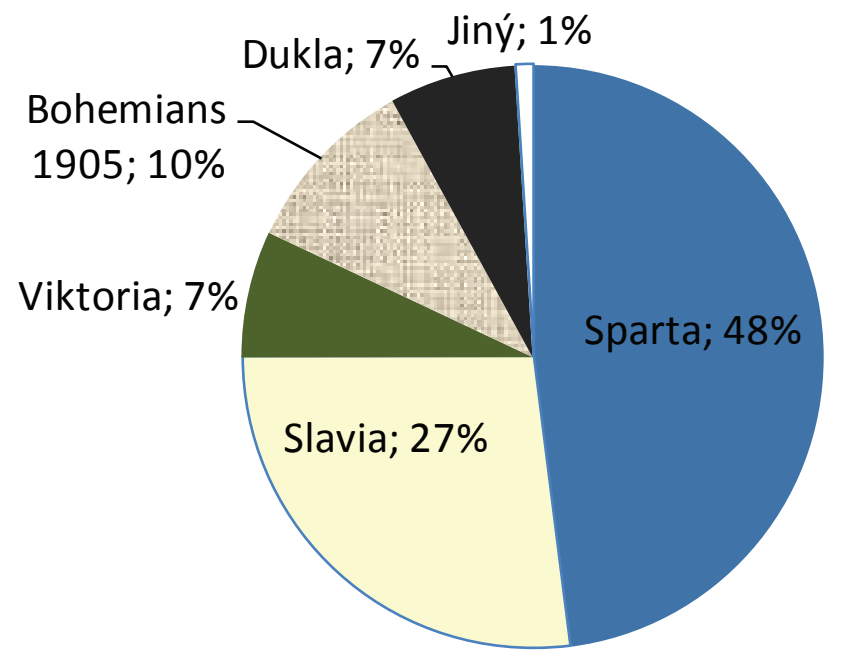

Graf 6: Rozděleni fanoušků mezi pražské ligové kluby

Při statistickém třídění fanouškovské základny podle pohlaví je zajímavé zjištění, že významně vyšší procento žen fandí klubu AC Sparta Praha, a naopak významně nižší procento žen fandí klubu FK Viktoria Žižkov.

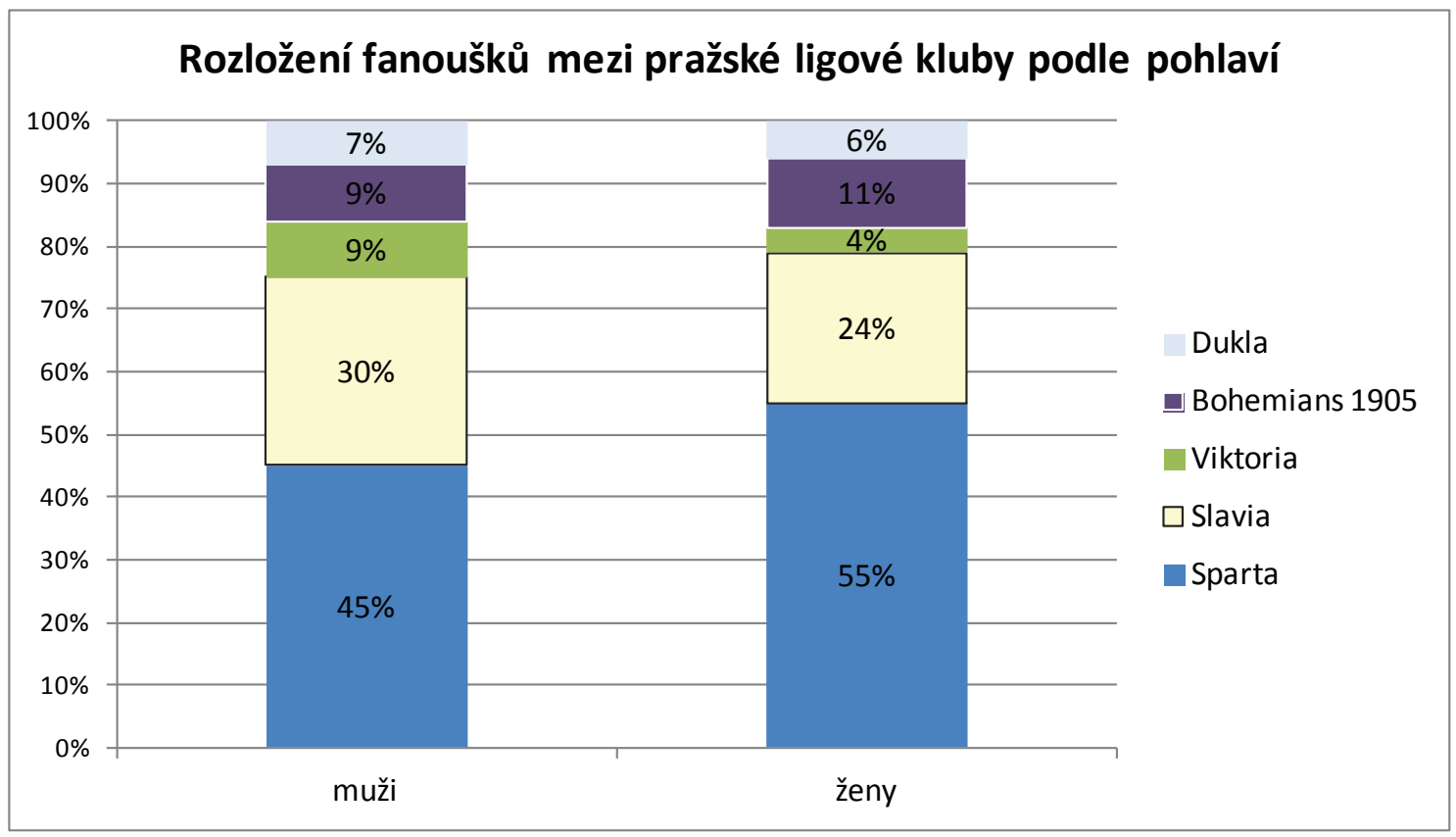

Graf 7: Rozdělení fanoušků mezi pražské ligové kluby podle pohlaví 


\section{Věrnost klubu a dědičnost fandovství}

Fandovství klubu se vyznačuje jedinečností, tzn. typický fanoušek je př́znivcem právě jednoho klubu. Jen 4 \% př́znivců pražského ligového fotbalu fandí více klubům z této ligy.

Další skutečností, která je v souladu s předpokládanou hypotézou, je vysoká loajalita svému klubu. $91 \%$ respondentů je celoživotně věrných svému klubu, jen $9 \%$ svi̊j oblíbený klub někdy změnilo.

$\mathrm{V}$ rámci této studie byla analyzována i dědičnost fandovství klubu v rámci rodiny. Také zde byla potvrzena významnost tohoto faktoru. Z výzkumu vyplynulo, že 61 \% respondentů deklaruje v rámci své rodiny dědičnost fandovství konkrétnímu klubu.

\section{DISKUSE}

Výsledky výzkumu potvrdily, že fotbal je divácky atraktivní sport. Svědčí o tom hodnota 79 \%, vyjadřující procento pražské populace, které se o tento sport zajímá.

$\mathrm{Z}$ marketingového hlediska je $\mathrm{v}$ rámci diskuse zajímavé provést také analýzu sociodemografického profilu těch obyvatel, kteří se o fotbal nezajímají. Pokud jde o věk, je zde statisticky významně zastoupena věková skupina 30-49 let. Pokud jde o pohlaví, převažují ženy. Konkrétně je v této skupině 26 \% žen a 74 \% mužů. Pokud jde o vzdělání, statisticky významně se o fotbal méně zajímají lidé s maturitou a statisticky významně se o fotbal zajímají lidé bez maturity.

Zajímavé je také zjištění, že dědičnost fandovství klesá s úrovní nejvyššího dosaženého vzdělání. Zatímco u lidí se základním vzděláním je dědičnost fandovství deklarována na úrovni $72 \%$, u lidí s vysokoškolským vzděláním je to již jen $48 \%$. Průměrná hodnota dědičnosti fandovství v rodině je $61 \%$.

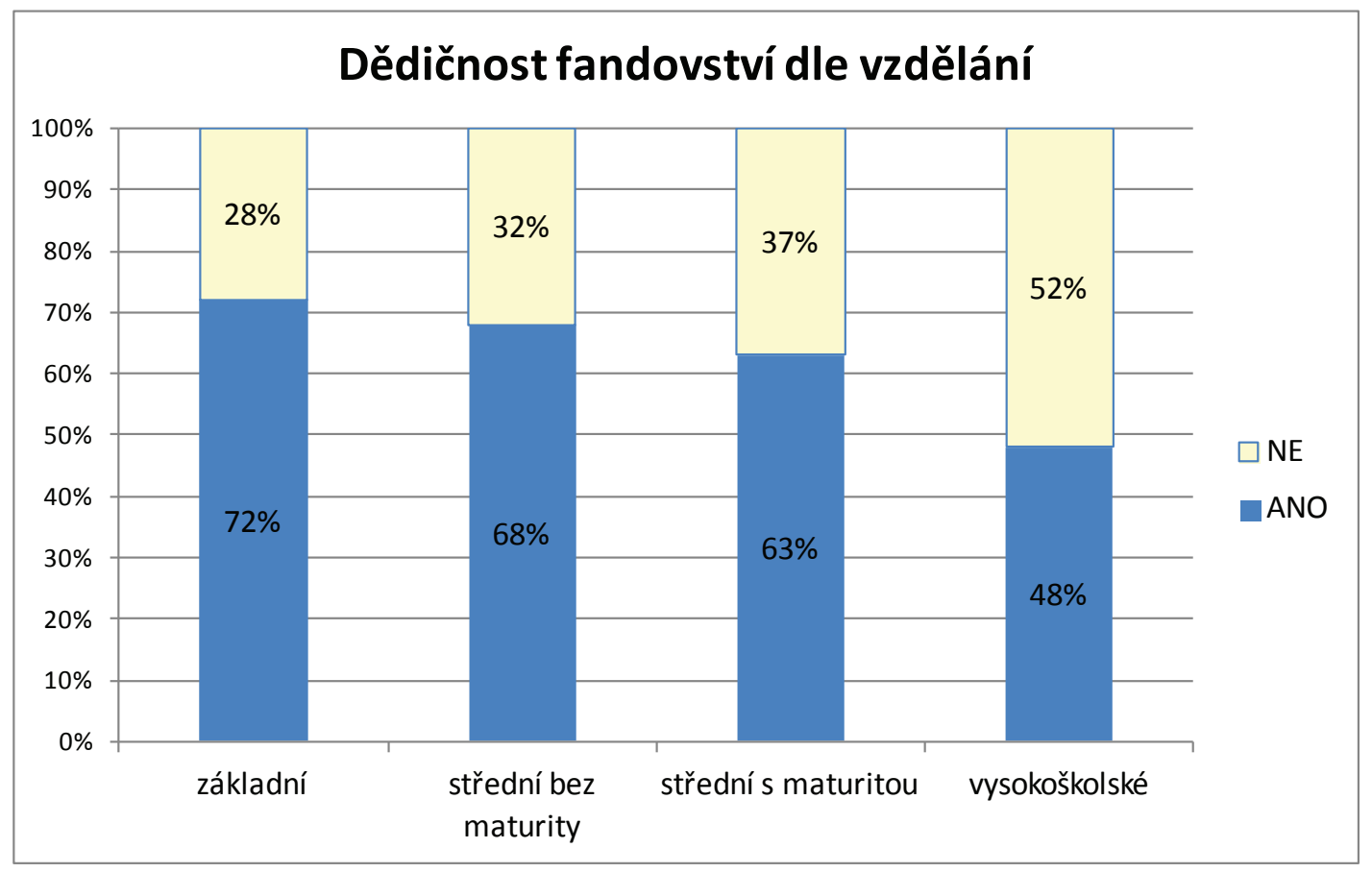

Graf 8: Dědičnost fandovství podle nejvyššiho dosaženého vzdělání

Na závěr je dobré zdůraznit, že vazba mezi sportem a marketingem nabírá na intenzitě a tento trend zřejmě bude pokračovat i v budoucnu. Jednou z klíčových aktivit marketingových útvarů firem je založit a udržet dlouhodobý vztah se zákazníky. Využití sportovních akcí pro marketingovou komunikaci, pro oslovení zákazníků, realizaci aktivačních kampaní a mediální zviditelnění je velmi vhodné (Kaynak, 2008). Znalost profilu sportovních fanoušků je pro nalezení a udržení takovéhoto vztahu klíčová. 


\section{ZÁVĚRY}

Toto reprezentativní výzkumné šetření zmapovalo pražskou populaci z hlediska vztahu $\mathrm{k}$ fotbalu a pražským ligovým fotbalovým klubům přineslo informace o velikosti jejich fanouškovské základny a její sociodemografické struktuře.

Detailní analýza dat přinese sportovním marketérům možnost přesněji cílit komunikační kampaně. Bude využitelná při targetingu sponzorských a aktivačních programů. Kromě toho i samotné fotbalové kluby budou moci informací využít zejména při rozvoji svých aktivit v oblasti ticketingu a merchandisingu.

Provedený výzkum přinesl následující odpovědi na stanovené výzkumné otázky:

1. $79 \%$ procent pražské populace fandí fotbalu.

2. Rozložení fanoušků mezi pražské ligové kluby je následující:

AC Sparta Praha $48 \%$

SK Slavia Praha $27 \%$

Bohemians $190510 \%$

FK Dukla Praha $7 \%$

FK Viktoria Žižkov $7 \%$

3. Typický fotbalový fanoušek je muž ve věku 20-39 let se středním vzděláním bez maturity.

4. Fandovství některému z pražských fotbalových týmů je výrazné v Praze 10 (dosahuje hodnoty 91 \%), kde sídlí SK Slavia Praha a Bohemians 1905. Naopak v Praze 1 a 5 je fandovství nejméně výrazné. V těchto městských částech nesídlí žádný tradiční fotbalový klub.

5. Zároveň se potvrdil předpoklad, že naprostá většina fanoušků (96 \%) má právě jeden oblíbený tým. Celoživotní věrnost fotbalovému klubu je u 91 \% pražské populace. Respondenti v 61 \% př́padů deklarují dědičnost fandovství fotbalovému klubu v rámci rodiny.

\section{LITERATURA}

FULlERTON, S. \& MERZ, G. R. (2008). The Four Domains of Sports Marketing. Sport Marketing Quarterly. 17(2), 90-108.

IRWIN, R. L. , LACHOWETZ, T. \& CLARK, J. (2010). Cause-related sport marketing: Can this marketing strategy affect company decision-makers? Journal of Management and Organisation, 16(4), 550-556.

KARLÍČEK, M. (2013). Základy marketingu. (1). Praha: Grada Publishing.

KAYNAK, E. , SALMAN, G. G. \& TATOGLU, E. (2008). An integrative framework linking brand associations and brand loyalty in professional sports. Journal of Brand Management. 15(5), 336-357.

KOZEL, R. (2006). Moderní marketingový výzkum. (1). Praha: Grada.

LEE, S. (2010). Marketing through sport. International Review on Public and Non-Profit Marketing, 7(1), 87-96.

RATTEN, V., RATTEN, H. (2011). International sport marketing: practical and future research implications. The Journal of Business \& Industrial Marketing, 26(8), 614-620.

ROSCA, V. (2011). Improving sport brands' reputation through marketing event. Academy of Economic Studies, 6(4), 605-626.

STŘíTESKÝ, V. (2011). Možnosti demografické segmentace při cílení reklamy na internetu. In: R. Bačuvčík, Tradiční a nové v marketingové komunikaci (165-172). 